\title{
Eggshell Thickness Variation in Red-legged Partridge (Alectoris rufa) from Spain
}

\author{
Aurora M. Castilla, ${ }^{1,2,6}$ Juan Martínez de Aragón, ${ }^{3}$ Anthony Herrel, ${ }^{4}$ and Søren Møller ${ }^{5}$
}

\begin{abstract}
Eggshell thickness is commonly used as an indicator of habitat quality and effects of environmental pollution on avian reproduction. We present the first data available on eggshell thickness for Red-legged Partridge (Alectoris rufa) in Spain. We compared eggshell thickness between eggs collected in an agricultural area (wild eggs) and eggs from game farms (farm eggs). Wild eggs had shells significantly thicker $(\bar{x}=0.32 \mathrm{~mm}, n=74)$ than farm eggs $(\bar{x}=$ $0.28 \mathrm{~mm}, n=89$ ), despite game farm partridges being fed a diet rich in calcium and not exposed to agricultural pollutants. Eggshell thickness did not affect hatching success of wild partridges, and population decline observed in this species cannot be linked to reduction in egg viability due to eggshell thickness. Received 8 February 2008. Accepted 6 May 2008.
\end{abstract}

Reduction of egg viability is an important cause of reproductive failure and has been suggested to contribute to decreases of bird populations (Drent and Woldendorp 1989, Cooper et al. 2005). Eggshell quality and reproduction of bird species is greatly affected by levels of calcium availability (Graveland and Drent 1997, Dhondt and Hochachka 2001, Tilgar et al. 2005), which in turn can be affected by levels of pesticides (Dauwe et al. 2006) or acidification (Nybø et al. 1997, Pollentier et al. 2007).

\footnotetext{
${ }^{1}$ Estación Biológica de Sanaüja (CSIC), Ministerio de Ciencia e Innovación; Ap. Correos $n^{\circ}$ 35, 25280 Solsona, E-Lleida, Spain.

${ }^{2}$ Department of Biodiversity and Evolutionary Biology, Museo Nacional de Ciencias Naturales de Madrid (CSIC), C/José Gutiérrez Abascal 2, E-28006 Madrid, Spain.

${ }^{3}$ Área de Defensa del Bosc, Centre Tecnològic Forestal de Catalunya, Pujada del seminari, s/n, E-25280, Solsona, Spain.

${ }^{4}$ Department of Organismic and Evolutionary $\mathrm{Bi}$ ology, Harvard University, 26 Oxford Street, Cambridge, MA 02138, USA.

${ }^{5}$ Roskilde University Library, P. O. Box 258, DK4000 Roskilde, Denmark.

${ }^{6}$ Corresponding author; e-mail: aurora@mncn.csic.es
}

High levels of pesticides are related to reduction in eggshell thickness in many species (Bunck et al. 1985, Peakall and Lincer 1996, Falk et al. 2006). Thus, eggshells are reasonable indicators of polluted areas, and can be used to monitor health of populations over long periods (Falk et al. 2006). However, long-term thinning of eggshells may not universally be related to pollution. A large decline in eggshell thickness in different species of thrushes (Turdus spp.) from different countries has been observed since before the introduction of organochlorine pesticides, but the cause of the decline is still unknown (Green 1998, Scharlemann 2003).

The Red-legged Partridge (Alectoris rufa) has been decreasing throughout its range (Meriggi and Mazzoni 2004 and references herein). Lack of reproductive success has been mainly attributed to food scarcity due to agricultural practices and nest predation (Potts 1980). However, the reproductive biology of this species is poorly known (Cabezas-Díaz et al. 2005) and little information is available about eggshell characteristics, which could affect reproductive success.

Our objectives were to measure shell thickness of eggs of Red-legged Partridge from a wild population to compare with those from a population where partridges had no food limitations, were putatively not subjected to agricultural pollution, and were known to have high hatching success. We tested the prediction that eggshells from the wild population should be thinner than those from the game farm population.

\section{METHODS}

We collected depredated and deserted eggs of Red-legged Partridge in the wild (Lleida, Catalonia, northeast Spain) during May to September 2002 and 2003. The procedure for locating eggs was to walk slowly through the study area where reproductive pairs and in- 
cubating females were previously observed, while looking under bushes and herbs. Most eggs were found isolated and dispersed in the field. Others were collected with the help of hunters, game keepers, and volunteers in an area of 1,500 ha. We were unable to distinguish if isolated eggs belonged to the same nest or not. In the absence of knowledge of predator behavior, substrate inclination, or the distances eggs could roll when pushed from the nest by sheep (e.g., Castilla and Rodriguez 2002), we assumed that all eggs are independent samples. When eggs were found in nests $(n=19)$, only a single egg was used to exclude dependence of data.

The study area is dominated by cultivated areas mainly cereals (barley, wheat, and oats), Prunus dulcis and Olea europaea, mixed with grasses and woodlands (e.g., Quercus ilex, $Q$. coccifera, Q. humilis, Rosmarinus officinalis, Thymus spp.). The area is used for livestock production and agricultural crops (cereal grains, almonds, and olive trees). Seeds treated with fungicides and insecticides are used. These seeds are consumed by partridges (Castilla 2003). A large variety of herbicides and fertilizers (organic and mineral) are applied on farm fields (Castilla et al. 2008b).

We obtained 89 partridge eggs from game farms in central Spain (Burgos, $n=35$ ) and northeast Spain (Barcelona, $n=54$ ). Each egg originated from a different individual. Nondeveloped eggs were infertile and unincubated. Unknown eggs were infertile or aborted in different stages after incubation. Both farms were near urban areas and far from agricultural fields.

We opened and examined the content of intact eggs to assess if they were developed or not. Eggs having yolk or small embryos $<10$ days development and depredated eggs having small holes from which a developed chick could not have been taken by predators were classified as not fully developed (Castilla et al. 2008a). Pieces of broken eggs found in the wild were classified as unknown, because we had no evidence that allowed us to infer their developmental stage. Non-developed eggs in game farms were infertile and not incubated. Unknown eggs were aborted during incubation and their developmental stage was not ascertained.

Eggshells were cleaned, the membrane re- moved, and eggshell thickness measured around the equator. All measurements were performed by the same person using a micrometer (Mitutoyo) to the nearest $0.001 \mathrm{~mm}$.

We used one-way ANOVA to test differences in eggshell thickness by developmental stages and from different sources. Mean values were compared with a post-hoc test (Fischer's protected least significant difference, $P$ $\leq$ 0.05). Analyses were performed using SPSS V13 (Statistical Package for the Social Sciences, Chicago, Illinois, USA).

\section{RESULTS}

Mean eggshell thickness for eggs collected in the wild was $0.329 \mathrm{~mm}(\mathrm{SD}=0.047$, range $=0.20-0.42 \mathrm{~mm}, n=74)$. Eggshell thickness was similar for eggs from the two game farms for development stage $1\left(F_{1,50}=1.07, P=\right.$ $0.310)$ or unknown stage $\left(F_{1,50}=0.91, P=\right.$ 0.351 ), and we pooled the data. No significant effect of development stage was found on eggshell thickness for game farm eggs $\left(F_{2,86}\right.$ $=0.69, P=0.512)$. Mean eggshell thickness of game farm eggs was $0.284 \mathrm{~mm}$ (SD = 0.03 , range $=0.21-0.34 \mathrm{~mm}, n=89)$. Eggshell thickness of wild $(n=74)$ versus game farm eggs $(n=89)$ was significantly different $\left(F_{1,162}=55.38, P<0.001\right)$ (Table 1$)$.

\section{DISCUSSION}

Variation in egg shell thickness has not been reported to our knowledge for any partridge species in the wild, and has only been reported for Rock Partridge (Alectoris graeca) in a game farm $(0.228 \mathrm{~mm})$ (Tilki and Saatci 2004). Body size and egg size of Rock Partridge are similar to that of Red-legged Partridge (Cramp and Simmons 1980). We found that eggshell thickness was higher for wild birds versus the game farm population, despite females in game farms being fed a calciumrich diet and were not exposed to farming or agricultural pollution. Egg size and wing size of wild and farm Red-legged Partridge are similar in our study site (Castilla and Pastor 2002, Castilla and Martínez in press), but body mass of game farm partridges (398-496 g) is higher than that of wild partridges (327$448 \mathrm{~g}$ ) of $\sim 4-6$ months of age (Castilla and Pastor 2002). It has been shown that strongerthicker eggs correspond to heavier bird species (Ar et al. 1979) but, we compared pop- 
TABLE 1. Eggshell thickness ( $\mathrm{mm}$ ) of eggs collected in the wild (Sanaüja, Lleida, Spain) or in game farms (Barcelona: B and Burgos: BU, Spain) with different developmental stages.

\begin{tabular}{|c|c|c|c|c|c|c|c|}
\hline & \multicolumn{3}{|c|}{ Wild $(n=74)$} & \multicolumn{4}{|c|}{ Game farm $(n=89)$} \\
\hline & \multicolumn{2}{|c|}{ Not developed } & \multirow{2}{*}{$\begin{array}{c}\text { Unknown } \\
\text { Depredated }\end{array}$} & \multicolumn{2}{|c|}{ Not developed } & \multicolumn{2}{|c|}{ Unknown } \\
\hline & Deserted & Depredated & & B & $\mathrm{BU}$ & B & $\mathrm{BU}$ \\
\hline Mean & 0.25 & 0.338 & 0.332 & 0.283 & 0.276 & 0.290 & 0.280 \\
\hline $\mathrm{SD}$ & 0.04 & 0.04 & 0.04 & 0.02 & 0.03 & 0.03 & 0.03 \\
\hline Max & 0.29 & 0.407 & 0.419 & 0.337 & 0.325 & 0.335 & 0.331 \\
\hline Min & 0.20 & 0.254 & 0.202 & 0.241 & 0.211 & 0.239 & 0.221 \\
\hline$n$ & 3 & 24 & 47 & 31 & 21 & 23 & 14 \\
\hline
\end{tabular}

ulations of about the same body size and mass. Female partridges in game farms lay more eggs $(\bar{x}=50)$ than those in the wild $(\bar{x}$ $=10$ ) (Castilla and Rodriguez 2002; game farms, pers. comm.), which may result in eggshell thinning in game farm populations.

Overall hatching success in game farms is high (>80-90\%, game farm data). We observed a large number of chicks ( 8 to14/brood in the wild population) after the hatching period in May (Castilla and Martínez in press), suggesting that hatching success may also be high in the wild. Eggshell thickness in our wild partridge population does not appear to affect hatching success. Thus, the population decline that has been observed since the early 1970 s in our study site should not be linked to the reduction in egg viability due to eggshell thickness.

Eggshell thickness may not be implicated in range-wide declines of Red-legged Partridge. However, our finding should be explored in other studies conducted at larger scales. Eggshell thickness and hardness can be extremely variable due to factors including pollution, individual female, clutch size, sequence of laying, egg characteristics, developmental stage, etc. (Falk and Møller 1990, Burger et al. 1995, Massaro and Davis 2004, Gosler et al. 2005, Higham and Gosler 2006, Kemps et al. 2006, Castilla et al. 2007). However, for many species the causes of eggshell thickness variation remain unknown (e.g., Green 1998, Scharlemann 2003). More basic research is needed to fully understand the factors affecting eggshell thinning in bird populations.

\section{ACKNOWLEDGMENTS}

We greatly thank hunters (Esteve Caus, Patxi Igual, Francesc Oliva) and students from Escola de Capaci- tació Agrària del Solsonès and of Sanaüja for collecting eggs in the field. Altube S.A. and Generalitat de Cataluña (Torreferrusa) provided eggs from game farm birds. Juan Ramón Arias, J. W. Connelly, C. E. Braun, and an anonymous referee contributed with interesting comments. This work was conducted on a contract "Ramón and Cajal" from the Spanish National Science Foundation-MEC (to AMC). AH is a postdoctoral fellow of the FWO-Vl.

\section{LITERATURE CITED}

Ar, A., H. Rahn, And C. V. Paganelly. 1979. The avian egg: mass and strength. Condor 81:331337.

Bunck, C. M., J. V. Spann, O. H. Pattee, and W. J. FLEMING. 1985. Changes in eggshell thickness during incubation: implications for evaluating the impact of organochlorine contaminants on productivity. Bulletin of Environmental Contamination and Toxicology 35:173-182.

Burger, J., K. Viscido, AND M. GoChFeld. 1995. Eggshell thickness in marine birds in the New Cork Bight - 1970s to 1990s. Archive of Environmental Contamination and Toxicology 29:187-191.

Cabezas-Diaz, S., E. Virgos, and R. Villafuerte. 2005. Reproductive performance changes with age and laying experience in the Red-legged Partridge Alectoris rufa. Ibis 147:316-323.

Castilla, A. M. 2003. ¿Qué comen las perdices? Caza and Pesca 690:8-12.

Castilla, A. M. and J. Martínez. In Press. Adaptación de las perdices (Alectoris rufa) al campo: la forma de recuperar poblaciones y disfrutar de la caza. Repofot, Madrid, spain.

Castilla, A. M. and E. Pastor. 2002. Comportamiento de la perdiz roja (Alectoris rufa) ante depredadores aéreos y terrestres: Comparación entre perdices de campo (Encomienda de Mudela, Ciudad Real) y de granja (Altube S.A.). ExLibris, Madrid, Spain.

Castilla, A. M. AND C. RodríGuez. 2002. Influencia de la depredación y de otros factores sobre la pérdida de nidos de perdiz roja (Alectoris rufa) en la Encomienda de Mudela, Castilla La Mancha (Ciudad Real). Serie Técnica. Ed. Organismo Autónomo Parques Nacionales, Ministerio de Medio Ambiente, Madrid, Spain. 
Castilla, A. M., A. Herrel, G. Díaz, and A. FranCESCH. 2007. Developmental stage affects eggshell breaking strength in two ground-nesting birds: the partridge (Alectoris rufa) and the quail (Coturnix japonica). Journal of Experimental Zoology 307A:471-477.

Castilla, A. M., S. Reig, J. Martínez de Aragón, AND A. DhONDT. 2008a. Developmental stage of failed eggs in the Red-legged Partridge Alectoris rufa. Journal of Ethology in press.

Castilla, A. M., T. Dauwe, I. Mora, M. Palmer, And R. Guitart. 2008b. Development and mortality of the yellow mealworm Tenebrio molitor exposed to fertilizers and herbicides commonly used in agriculture. Vie et Milieu-Life and Environment 58:In press.

Cooper, C. B., W. M. HochachKa, G. Butcher, And A. A. DHondT. 2005. Egg viability as an explanation for seasonal and latitudinal trends in clutch size. Ecology 86:2018-2031.

Cramp, S. AND K. Simmons. 1980. Handbook of the birds of Europe, the Middle East and north of Africa. The birds of the western Paleartic. Oxford University Press, Oxford, United Kingdom.

Dauwe, T., V. L. B. Jaspers, A. Covaci, And M. Eens. 2006. Accumulation of organochlorines and brominated flame retardants in the eggs and nestlings of Great Tits, Parus major. Environmental Science and Technology 40:5297-5303.

Dhondt, A. A. And W. HochachKa. 2001. Variations in calcium use by birds during the breeding season. Condor 103:592-598.

Drent, P. J. AND J. W. WoldENDORP. 1989. Acid rain and eggshells. Nature 339:431.

FALK, K. AND S. MøLlER. 1990. Clutch size effects on eggshell thickness in the Peregrine Falcon and European Kestrel. Ornis Scandinavica 21:265-269.

Falk, K., S. Møller, And W. Mattox. 2006. A longterm increase in eggshell thickness of Greenlandic Peregrine Falcons Falco peregrinus tundrius. Science of the Total Environment 355:127-134.

Gosler, A. G., J. P. Higham, and J. Reynolds. 2005. Why are birds'eggs speckled? Ecology Letters 8: 1105-1113.

Graveland, J. And R. H. Drent. 1997. Calcium availability limits breeding success of passerines on poor soils. Journal of Animal Ecology 66:279288 .

GREEN, R. E. 1998. Long-term decline in the thickness of eggshells of thrushes, Turdus spp. Proceedings of the Royal Society of London Series B-Biological Sciences 265:679-684.

Higham, J. P. And A. G. Gosler. 2006. Speckled eggs: water-loss and incubation behaviour in the Great Tit Parus major. Oecologia 149:561-570.

Kemps, B. J., T. Govaerts, B. De Ketelaere, K. Mertens, F. R. Bamelis, M. M. Bain, E. M. DecuyPERE, AND J. G. DE BAERDEMAEKER. 2006. The influence of line and laying period on the relationship between different eggshell and membrane strength parameters. Poultry Science 85:13091317.

Massaro, M. And L. S. Davis. 2004. The influence of laying date and maternal age on eggshell thickness and pore density in Yellow-eyed Penguins. Condor 106:496-505.

Meriggi, A. And R. Mazzoni. 2004. Dynamics of a reintroduced population of Red-legged Partridges Alectoris rufa in central Italy. Wildlife Biology 10:1-9.

Nyb $\varnothing$, S., M. Staurnes, And K. Jerstad. 1997. Thinner eggshells of Dipper (Cinclus cinclus) eggs from an acidified area compared to a non-acidified area in Norway. Water Air and Soil Pollution 93: 25-266.

Peakall, D. B. And J. L. Lincer. 1996. Do PCBs cause eggshell thinning? Environmental Pollution 91:127-129.

Pollentier, C. D., K. P. Kenow, and M. W. Meyer. 2007. Common Loon (Gavia immer) eggshell thickness and egg volume vary with acidity of nest lake in northern Wisconsin. Waterbirds 30: 367-374.

PotTs, G. 1980. The effects of modern agriculture, nest predation and game management on the population ecology of partridges Perdix perdix and Alectoris rufa. Advances in Ecological Research 11: $1-82$.

Scharlemann, J. P. W. 2003. Long-term declines in eggshell thickness of Dutch thrushes Turdus spp. Ardea 91:205-211.

Tilgar, V., R. Mand, P. Kilgas, And S. J. Reynolds. 2005. Chick development in free-living Great Tits Parus major in relation to calcium availability and egg composition. Physiological and Biochemical Zoology 78:590-598.

TILKI, M. AND M. SAATCI. 2004. Effects of storage time on external and internal characteristics in partridge (Alectoris graeca) eggs. Revue de Medecine Veterinaire 155:561-564. 